
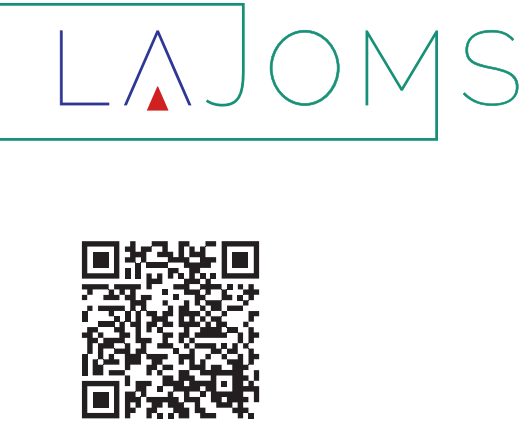

Octubre - Diciembre 2021 Vol. 1, núm. 1 / p. 6

\title{
Palabras inaugurales del Editor en Jefe
}

\author{
Opening remarks by the Editor-in-Chief
}

Luiz Fernando Lobo Leandro*

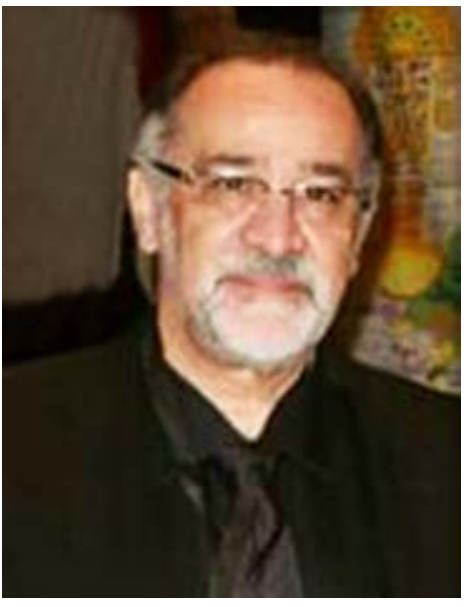

Amigos, compañeros y colegas, este momento es el comienzo de una realidad soñada desde hace algunos años. En nuestro mundo científico no hay forma de difundir y agregar conocimiento sin tener un vehículo de comunicación. Aquí hay una revista, pero no cualquiera, sino una «Revista» de un continente rico en profesionales que tienen mucho que aportar a la comunidad científica de

todo el mundo. No fue fácil, fueron necesarios años de reuniones y de estudios para lograr este formato, fueron varias personas que son ejemplo en sus países y representan mucho al mundo, despojadas de sus vanidades para que el grupo de la Asociación Latinoamericana de Cirugía y Traumatología Bucomaxilofacial (ALACIBU) pudiera tener sus revistas. Abrimos una puerta para que los residentes contribuyan y comiencen su vida científica y para que las universidades latinas permitan a los colegas latinos mostrar quiénes somos y qué somos. Ahora espero que vayamos todos juntos para que este proyecto sea eterno. Mencionar nombres al final de la presentación podría ser injusto, porque de alguna manera todos contribuyeron de manera decisiva para llegar hasta aquí. Ahora veremos a todos en nuestro próximo Congreso Internacional de la Asociación Latinoamericana de Cirugía y Traumatología Bucomaxilofacial (CIALACIBU).

Correspondencia:

Prof. Dr. Luiz Fernando Lobo Leandro

E-mail:drlobo@drlobo.com.br

Citar como: Lobo LLF.

Palabras inaugurales del Editor en Jefe. Lat Am J Oral Maxillofac

Surg. 2021; 1 (1):

6. https://dx.doi. org/10.35366/101910

* Cirujano Maxilofacial Oral. Editor en Jefe de LAJOMS. Certificado por el Board de ALACIBU. Miembro asociado de la Asociación Europea de Cirugía Maxilofacial.

doi: 10.35366/101910 